ESJ Humanities

\title{
Selecting Indicators for Assessing Neighbourhood Sustainability: The Metropolitan Lagos Workflow
}

\author{
Vincent Onyango, PhD \\ Solomon Ayomikun Adewumi, PhD \\ Architecture \& Urban Planning, \\ University of Dundee, Scotland, United Kingdom
}

Doi: 10.19044/esj.2021.v17n2p170

Submitted: 24 November 2020

Accepted: 08 January 2021

Published: 31 January 2021
Copyright 2021 Author(s)

Under Creative Commons BY-NC-ND

4.0 OPEN ACCESS

Cite As:

Onyango V. \& Adewumi A.S. (2021). Selecting Indicators for Assessing Neighbourhood Sustainability: The Metropolitan Lagos Workflow. European Scientific Journal, ESJ, 17(2), 170. https://doi.org/10.19044/esj.2021.v17n2p170

Abstract

Neighbourhood Sustainability Assessment Frameworks (NSAFs) are increasingly touted as crucial in planning and designing sustainable urban neighbourhoods. Ostensibly, NSAFs ensure that sustainability concerns are duly addressed following the recognition that neighbourhoods are key building blocks of urban areas. While the NSAF discourse has largely involved developed countries, the selection of appropriate indicators to use in an NSAF has remained a problem often because of little robust evidence to support the selected indicators. Also, as develoing countries are largely absent in this discourse, this paper presents an exemplar approach and workflow for selecting NSAF indicators for a Sub-Saharan Africa (SSA) context. Positivist techniques (weighted average, co-efficiency of variation, and content validity in ratio) are used to rank the significance of the stakeholders' indicated perceptions and preferences collected using questionnaire surveys from metropolitan Lagos. This paper's significance lies in showcasing the robust methodological approach and sound evidence-base for selecting the indicators based on input form diaparate stakeholders: including data requirements and workflow that SSA countries can easily adopt.

Keywords: Neighbourhood Sustainability Assessment Framework, Indicators, Metropolitan Lagos, Sub-Saharan Africa 



\section{Introduction}

Urban sustainability is the idea that a city can be organised to create the smallest possible ecological footprint: producing the lowest quantity of pollution, efficiently using resources, contributing minimally to climate change whilst providing a high quality of welfare and wellbeing for its people (Tetteh and Amponsah, 2020; Gehl and Svarre, 2013). Despite considerable rhetoric from built environment professionals and policy-makers, the progress in achieving urban sustainability has remained static and slow. However, a recent turn in the quest for urban sustainability is the recognition that the neighbourhood level of planning is crucial for delivering transformative measures towards urban sustainability (UNEP, 2020; Ferwati et al., 2019; Moroke et al., 2019; Bullock et al., 2017; Dawodu et al., 2017).

This means conceptualising the neighbourhood as a building block for an urban area (Wangel et al., 2016): implying that urban sustainability will be unattainable if its component parts such as neighbourhoods are themselves unsustainable (Stanislav and Chin, 2019; Bahadure and Kotharkar, 2018). Thus, if the delivery frameworks e.g. design, planning and decision-making for neighbourhoods are themselves imbued with the visions, principles, targets and indicators of sustainability, then the resultant urban places will be more sustainable (UNEP, 2020). This is best illustrated in the development of Neighbourhood Sustainability Assessment Frameworks (NSAFs) to assist designing and planning for new neighbourhoods. As NSAFs gain increasing attention (Ameen and Mourshed, 2019; Bahadure and Kotharkar, 2018), this paper is concerned with the fact that most Sub-Saharan African countries (SSA) are yet to develop NSAFs suitable to their own needs and contexts (Yigitcanlar et al., 2015; Berardi, 2013).

The lack of NSAFs in SSA presents several challenges. Firstly, given SSA's high rate of urbanization and the potentially adverse impacts associated with it (UNDESA, 2019), how can urban sustainability be assured? Urbanization in SSA has grown rapidly from 15\% in 1960 to $40 \%$ in 2010 (Awumbila, 2017): with cities like Lagos, Cairo, Kinshasa, Addis Ababa growing into megacities of over 10 million inhabitants (UN-Habitat, 2015). Experiencing an annual urban population growth rate of $4.1 \%$ compared with a global rate of $2.0 \%$ (Saghir and Santoro, 2018), urban sustainability in SSA cannot therefore be ignored (Olvera et al., 2016; La Porta and Shleifer, 2014).

Secondly, the literature acknowledges that NSAFs are 'tailor-made' and 'context specific' (USGBC, 2018; Komeily and Srinivasan, 2015), making direct and wholesale importation of NSAFs to SSA problematic. As the vast discourse in NSAFs is largely western country oriented, it is not clear what the parameters for a SSA-context NSAF would be. Yet the SSA context is different in terms of socio-economic development, culture, political visions and aspirations, demography, the environment and climate etc. (Du Plessis, 
2005). Thirdly, experience from countries already ahead in using NSAFs have identified the issue of selecting appropriate context-specific indicators (Joss et al., 2015; Conte and Monno, 2012), as a key challenge (section 2.2). Therefore, what evidence and approach will guide the selection of robust inidcators for use in SSA-specifc NSAFs?

This paper aims to contribute to the development of SSA-context relevant NSAFs by focusing on how appropriate indicators may be selected. It presents a methodology and workflow, underpinned by the need to showcase a practical and robust process with valid outcomes. Three objectives are pursued:

- To show how a variety of values, perceptions and aspirations of different stakeholders are captured and aggregated, towards identfying appropraite indicators;

- To show deployment of several techniques to reliably support the selection of fit-for-purpose indicators, driven by clear criteria;

- To show how viability and feasibility of the selected indicators are assured.

This paper's strength lies in addressing the complex task of capturing the wide spectrum of stakeholder perspectives, which can be subjective, and analysing them within more objective techniques. This addresses the common problem of indicators being developed by experts and with little input from local communities who are key stakeholders in the neighbourhoods (USGBC, 2018; GBCA, 2012). Great attention is paid to the transparency and repeatability of the work, with aspects that enhance validity and reliability, signposted.

\section{The challenge}

Indicators are 'a representation of the characteristics of a given system, by a quantitative or qualitative variable'; 'a parameter, or a value derived from parameters, which serves to provide information about the state of a phenomenon/area' (Science for Environment Policy, 2015:8). Indicators are used in certification and accreditation schemes as standardised references to assess and monitor performance and progress (Cowley et al., 2013). Therefore, indicators help to communicate information in a structured manner in the decision-making process, making the concept of sustainability observable and demonstrable (Dahl, 2012). Bell and Morse (2004) also argue that indicators facilitate social learning as those involved can use indicators to better understand the key components and criteria that constitute what is considered 'sustainable' under various contexts.

Indicators can also be used for strategic visioning to define city-level strategies for urban sustainability; or used as parts of toolkits to guide step-by- 
step analysis, designing and implementing of urban sustainability projects against baseline measures and future targets. However, the vast literature on NSAFs have identified some key challenges and critical questions which require careful attention when selecting indicators to use. For example: acknowledging and balancing bewteen globally and locally relevant indicators (Joss et al., 2015); deciding who is involved in indicator selection and deciding whose interests are reflected in the indicators (Bond et al., 2012). It has alo ben noted that frequent over-reliance on experts-led approaches has led to democratic and legitimacy deficits (Berardi, 2013).

Therefore, a fit-for-purpose indicator set requires a delicate judgement across the various stakeholders and sustainability aspects, within a transparent and robust approach. This will serve to integrate the indicators in a way that truly reflects the key themes, the sensitivity of interests, and balances the relative roles and significance of the indicators. Empirically, this should meet thresholds of validity and reliability, as well precision and accuracy in the indicators as measurements (Komeily and Srinivasan, 2015), in a way that aligns with the aspirations of the users.

\section{Materials and methods}

To ameliorate experts-led approaches local stakeholders were targeted as key sources of information. This aligns with the critical realism philosophical stance which advocates an explanatory linkage that integrates people's understanding in relation to their contextual realities e.g. environmental, socio-economic, cultural, ethnic, political (Salama, 2019; Fletcher, 2017). A case study approach, based on metropolitan Lagos, was therefore considered most appropriate to contextualise the data and analysis, and provide insight that is likely to resonate with a majority of other urban areas in SSA.

\subsection{Methods and data collection}

Qualitative information on perceptions and relative preferences for the suitability of various indicators was collected from relevant stakeholders involved in delivering and using neighbourhoods. This was complemented by quantitative methods to statistically analyse and help explain the relative importances associated with each indicator. Table 1 showcases the workflow and the sequence of interconnected methods and techniques as the work progressively unfolded in three main phases. 
Table 1: The sequence of methods and data collection as applied in the study.

\begin{tabular}{|c|c|c|c|}
\hline Phase / purpose & $\begin{array}{l}\text { Method } \\
\text { technique }\end{array}$ & Data sources; analysis & Output \\
\hline $\begin{array}{l}\text { 1. Identifying generic } \\
\text { indicators }\end{array}$ & $\begin{array}{l}\text { Literature } \\
\text { review }\end{array}$ & $\begin{array}{lr}\text { Published } & \text { urban } \\
\text { sustainability } & \text { reports; } \\
\text { literature review } & \end{array}$ & $\begin{array}{l}\text { Candidate } \\
\text { indicators }\end{array}$ \\
\hline $\begin{array}{ll}2 . & \text { Selecting } \\
\text { appropriate } & \text { indicator } \\
\text { set } & \end{array}$ & Questionnaire & $\begin{array}{l}\text { Stakeholders in } \\
\text { planning; } \\
\text { neighbourhood } \\
\text { residents; Analytical } \\
\text { Hierarchy Process }\end{array}$ & $\begin{array}{l}\text { Indicator } \\
\text { weighting } \\
\text { ranking }\end{array}$ \\
\hline $\begin{array}{l}\text { 3. Validating indicator } \\
\text { set }\end{array}$ & Questionnaire & $\begin{array}{l}\text { Stakeholders } \\
\text { planning; Analytical } \\
\text { Hierarchy Process }\end{array}$ & $\begin{array}{l}\text { Selected } \\
\text { indicators. }\end{array}$ \\
\hline
\end{tabular}

\subsubsection{Identifying generic indicators}

Instead of considering indicators from scratch it was reasonable and cost-effective to start with what already exists in the wider literature, linking to already established knowledge and practice. Prominent international and local reports were targeted, including the New Urban Agenda adopted at United Nations Conference on Housing and Sustainable Urban Development (Habitat III) (UN-Habitat, 2016), which provided eight key commitments that define a sustainable urban area. The Sustainable Development Goal 11, aimed at delivering sustainable communities, which adopts ten targets and twenty indicators. At the continental level, the Africa Union Agenda 2063 proposed in 2014 adopts $7 \mathrm{key}$ aspirations to enhance sustainable development. The Nigerian National Urban Development Policy's vision for sustainable urban planning and design, adopts five sustainability agenda.

More locally, the Lagos State Development Plan (2012-2025) identifies four key issues of the plan (economic growth; infrastructure development; social development and security; and sustainable environment) (LASG, 2013), to which indicators can be subscribed. From these policy documents twenty-six sustainability themes applicable to planning at the neighbourhood level were identified and then clustered under 10 overarching themes. Fifty indicators were identified albeit with some overlap: and regrouped into twenty five 'headline indicators' which could be used in the decision-making process for a sustainable neighbourhood.

\subsubsection{Selecting appropriate indicator set}

The 25 indicators were used as a starting point, and to be revised and/or refined by stakeholders, in the quest for the most appropriate indicators for Lagos. This involved a hybrid two-step approach (Hak et al., 2012; Bell and Morse, 2008), applying a bottom-up approach to capture local perspectives; 
and then a top-down approach to capture experts' perspectives. To do this, questionnaires were sent to both residents of the neighbourhoods and experts in urban neighbourhoods (Table 2). The relevant institutions were approached and asked to nominate the experts to participate. The aim here was not to be representative of the institutions, but to ensure that views from each category was captured. Where more than one participant was required, the snowballing technique was used. A participant was asked to nominate other appropriate institutions or experts who were then invited to participate. Academics who have written extensively on neighbourhood planning in metropolitan Lagos were also invited to participate.

Table 2: Institutional stakeholders: questionnaires sent and received.

\begin{tabular}{|c|c|c|}
\hline Stakeholders & Institutions (abbreviation) & $\begin{array}{l}\text { Questionnaires } \\
\text { sent (retrieved) }\end{array}$ \\
\hline \multirow[t]{4}{*}{ Regulators } & $\begin{array}{l}\text { Ministry of Physical } \\
\text { Development (MPPUD) }\end{array}$ & 1 \\
\hline & Lagos State Building Control Agency (LASBCA) & 1 \\
\hline & $\begin{array}{l}\text { Lagos State Physical Planning and Development } \\
\text { Authority (LASPPDA) }\end{array}$ & 1 \\
\hline & New Town Development Authority (NTDA) & 1 \\
\hline \multirow[t]{4}{*}{ Developers } & Ministry of Housing $(\mathrm{MoH})$ & 1 \\
\hline & $\begin{array}{l}\text { Lagos State Development and Property corporation } \\
\text { (LSDPC) }\end{array}$ & 1 \\
\hline & Lagos Building Investment Company (LBIC) & 1 \\
\hline & Private Developer (PDEV) & $2(2)$ \\
\hline \multicolumn{3}{|l|}{$\begin{array}{l}\text { Built environment } \\
\text { professionals }\end{array}$} \\
\hline Town Planners & $\begin{array}{l}\text { New Town Development Authority } \\
\text { Lagos State Building Control Agency }\end{array}$ & $\begin{array}{l}3(3) \\
3(2) \\
\end{array}$ \\
\hline Builder & Ministry of Housing Architecture and Building & $3(2)$ \\
\hline Civil Engineer & Engineering & $3(1)$ \\
\hline Quantity Surveyor & Quantity Surveying & $3(1)$ \\
\hline \multirow[t]{2}{*}{ Academics } & Obafemi Awolowo University, Nigeria & $2(2)$ \\
\hline & University of New South Wales, Australia & 1 \\
\hline
\end{tabular}

Residents of three neighbourhoods were purposively selected to represent the common types of neighbourhoods in Lagos: i.e. built by Federal Government (neighbourhood A), State Government (neighbourhood B), and Private developers (neighbourhood C). A questionnaire survey was sent to the neighbourhoods as presented in Table 3. 
Table 3: Questionnaire distribution in the three selected neighbourhoods

\begin{tabular}{|l|l|l|}
\hline Neighbourhood & Design typologies / sectors / blocks & $\begin{array}{l}\text { Questionnaires } \\
\text { sent (retrieved) }\end{array}$ \\
\hline A & 4-storey block of 16 units of 2 bedroom flat & $65(57)$ \\
\cline { 2 - 3 } & 4-storey block of 8 units of 3 bedroom flat & $51(43)$ \\
\cline { 2 - 3 } & A row of 2-bedroom bungalow with courtyard & $35(25)$ \\
\cline { 2 - 3 } & A row of 3-bedroom flat duplexes & $32(25)$ \\
\hline \multirow{4}{*}{ B } & Sectors & $150(100)$ \\
\cline { 2 - 3 } & $1-25$ & $30(30)$ \\
\cline { 2 - 3 } & $26-30$ & $18(9)$ \\
\cline { 2 - 3 } & $31-33$ & $28(20)$ \\
\hline C & Blocks & \\
\cline { 2 - 3 } & A-N & \\
\hline
\end{tabular}

In neighbourhood $\mathrm{A}$, a stratified and systematic sampling led to one questionnaire being administered in every 5 th block in each neighbourhood typology. The '4-storey block of 16 units of 2-bedroom flats' was the dominant typology and therefore had the highest number of questionnaires administered. This was followed by the '4-storey block of 8 units of 3bedroom flats'. The questionnaires in neighbourhood B were administered using the 'sector' divisions of the neighbourhood. A sector usually comprises 15 to 22 blocks (a 2-storey building of 6 units of 3-bedroom flats), and each was represented in the sample. 6 questionnaires were administered in each sector. In sectors 1 to 25 , with an average of 18 blocks per sector, a questionnaire was administered in every 3rd block. In sectors 26 to 30, with an average of about 24 blocks per sector, a questionnaire was administered in every 4th block. In sectors 31 to 33 with an average of 12 blocks per sector, a questionnaire was administered in every 2 nd block.

Two questionnaires were administered in each of the 14 blocks in neighbourhood $\mathrm{C}$, consisting of 4 flats. The sampling aimed at giving the different types of neighbourhoods an equal chance to be included in the survey. In the questionnaires participants were asked to consider the 25 indicators and delete, revise or add others as they felt necessary. Participants were asked to indicate their perceptions on the importance of an indicator for urban sustainability using a 5-point Likert scale (1- Not important and dispensable; 2- Little importance but contribute insignificantly; 3-Important but only contributes slightly; 4- Important and contributes significantly; 5Highly important and indispensable).

To rank the indicator preferences a pair-wise comparison Analytical Hierarchy Process (AHP), a widely used technique to determine the relative weight of multiple criteria or options against a given parameter (Saaty and Peniwati, 2008), was applied. Participants were asked to first compare in pairs the sustainability dimensions (environmental, socio-cultural, and economic) 
with each other; followed by comparing the indicators under each sustainability dimension. This two-step allowed the researchers to deconstruct the complexity in understanding the relative preferences, by first dealing with the broader sustainability dimensions on their own, before addressing the indicators on their own. The preference ranking used a 9-point scale (Figure 1). A minimum of 5 respondents were targeted for each group of stakeholders, to generate enough data for statistical analysis.

1- Equal importance of both elements
3- Moderate importance of first element over the second; $1 / 3(0.33)$ - Moderate importance of
second element over the first
5- Strong importance of first element over the second; $1 / 5(0.20)$ - Strong importance of second
element over the first
7- Very strong importance of first element over the second; $1 / 7(0.14)$ - Very strong importance
of second element over the first
9- Extreme importance of first element over the second; $1 / 9(0.11)$ - Extreme importance of
second element over the first
The intermediate values 2,4,6,8 were similarly treated.

Figure 1: The 9-point Likert scale for pairwise comparison.

50 AHP questionnaires were sent out and 21 valid ones were retrieved giving a response rate of $58 \%$ (Table 4). The highest numbers of questionnaires were administered in the category of public developers (that is, Ministry of Housing; Lagos State Development and Property Corporation; and Lagos Building Investment Company) because they are the main channels for neighbourhood development in metropolitan Lagos.

Table 4: Participants in the AHP Questionnaire.

\begin{tabular}{|l|l|}
\hline Category of respondents & Questionnaires sent (received) \\
\hline Residents: & \\
$\quad$ Neighbourhood A & $5(1)$ \\
Neighbourhood B & $5(2)$ \\
Neighbourhood C & $5(1)$ \\
Private developers & $5(3)$ \\
Architecture and Building services & $5(4)$ \\
Quantity Surveying & $5(1)$ \\
Engineering & $5(2)$ \\
Town Planning & $5(4)$ \\
Lagos State Property Development Corporation & $5(2)$ \\
Lagos State Building Investment Company & $5(1)$ \\
\hline
\end{tabular}

The AHP analysis was done using the BPMSG (Business Performance Management Singapore) AHP Online system, to elicit relative weights to the indicators, acting as a support tool for decision-making on the indicators. It must be noted that the AHP technique does not rely on a large sample size (unlike the traditional survey) for validity (Schmidt et al., 2015). Cheng et al. (2002) further argued that the AHP technique may be impossible and 
impracticable for a survey with a large sample size as uninterested participants have a great tendency to provide arbitrary answers resulting to a high degree of inconsistency. For example, Dangana (2015) and Akadiri (2011) used 19 and 9 participants, respectively.

\subsubsection{Validating the indicator set}

This aimed to validate the selected indicators by using participants who were likely to use them e.g. regulators and planning authorities in metropolitan Lagos. Questionnaires were sent to an independent group from those that suggested the indictors (Table 5) were recruited for the validation exercise. The questionnaire was structured into four parts: (i) background information of participant; (ii) levels of agreement on comprehensiveness of indicator set; (iii) ranking, and; (iv) usability of the indicators. The benefit of this phase is to enhance the likely appropriateness of the selected indicators as fit for purpose e.g. in an NSAF.

Table 5: A validation questionnaire was sent and retrieved from each of the listed institutions including two private developers.

\begin{tabular}{|l|}
\hline Institutions \\
\hline Ministry of Physical Planning and Urban Development (MPPUD) \\
\hline Ministry of Works (MoW) \\
\hline Lagos State Building Control Agency (LASBCA) \\
\hline Lagos State Physical Planning and Development Authority (LASPPDA) \\
\hline New Town Development Authority (NTDA) \\
\hline Ministry of Housing (MoH) \\
\hline Lagos State Development and Property Corporation (LSDPC) \\
\hline Lagos Building Investment Company (LBIC) \\
\hline Private Developer (PDEV1) \\
\hline Private Developer (PDEV2) \\
\hline
\end{tabular}

\subsection{Data analysis}

The data from pair-wise rankings were analysed using Microsoft Excel function's descriptive statistics. The weighted average (WA) value showed the level of importance attached to an indicator by the stakeholders. The coefficient of variation $(\mathrm{CV})$, also the relative standard deviation, showed the extent of variability to the mean. The advantage is that the value of CV is independent of the unit in which the measurement has been taken, so it is a dimensionless number, allowing for comparison between data sets with different units or means. According to Wilson et al. (2012) and Lawshe (1975), an indicator with a $\mathrm{CV}$ value less than 0.5 can be said to be consensually agreed upon by the stakeholders.

Content validity ratio (CVR) was calculated to determine the degree to which the items on the measurement instrument represent the entire content domain: providing a numeric value indicating the degree of validity determined from expert's ratings. CVR values ranged from -1 
(perfect disagreement) to +1 (perfect agreement), with values above zero indicating that over half of the respondents agreed that a variable was essential (Ayre and Scally, 2013). From other studies an indicator with a CVR value equal to or greater than 0.29 was considered 'essential' based on stakeholders' perception (Wilson et al., 2012).

\section{$4 \quad$ Results and findings}

\subsection{Selecting the indicators}

The frequency distribution for each indicator, based on the institutional stakeholders' perceptions is presented in Figure 2, showing the extent to which participants thought indicators were important.

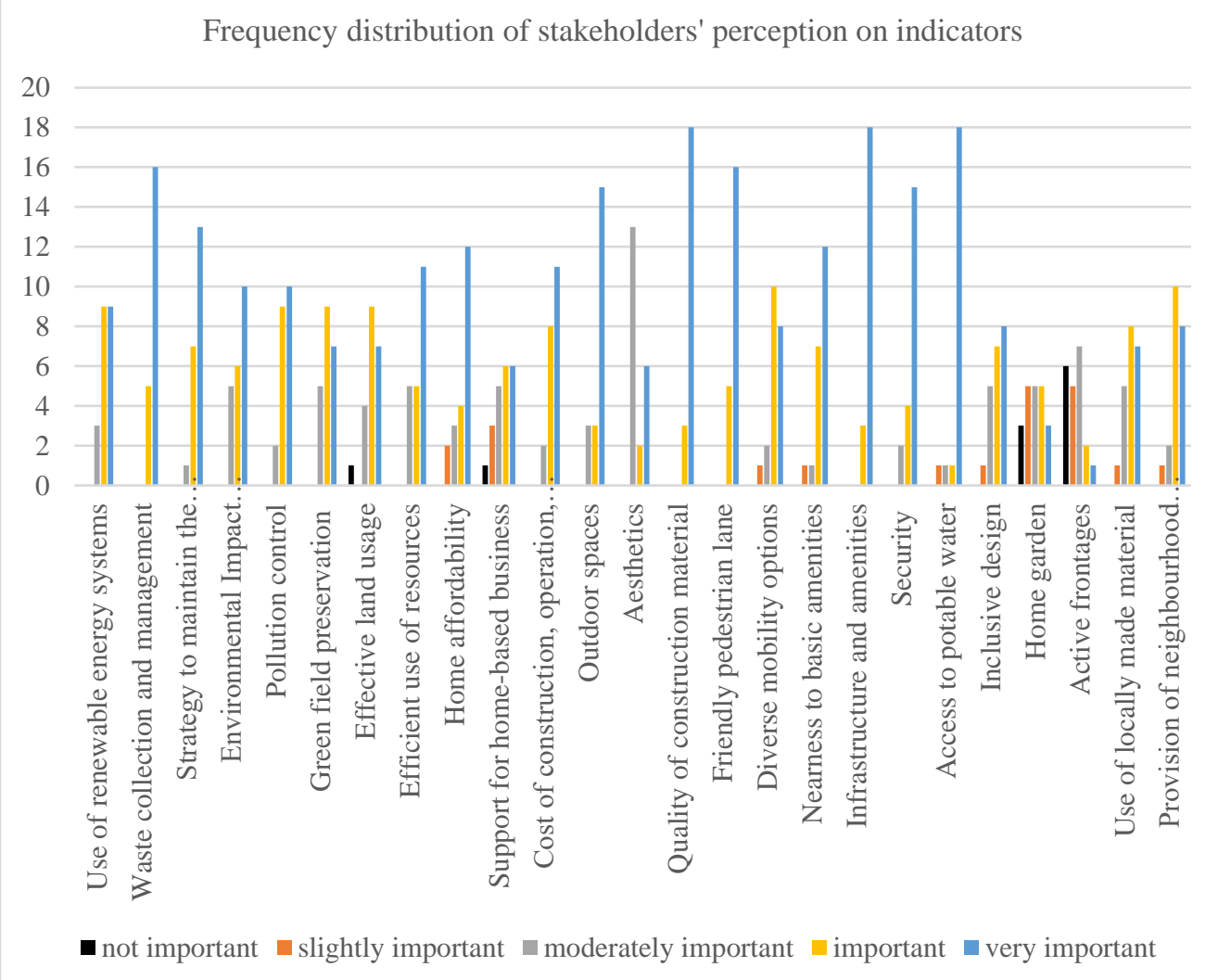

Figure 2: Frequency distribution for each indicator on a 5-point rating scale $(\mathrm{n}=21)$.

The institutional stakeholders' perceptions revealed three levels of popularity to which the importance of an indicator could be viewed. Firstly, only four (16\%) of the indicators ('Quality of construction material'; 'Friendly pedestrian lane'; Waste collection and management; and 'Infrastructure and amenities) were considered important by all the respondents. Secondly, 16 (64\%) of the indicators were considered important by about $75 \%$ of the 
respondents. Thirdly, two (8\%) of the indicators ('Aesthetics'; and 'Inclusive design') were considered important by more than $60 \%$ of the respondents.

Frequency distribution of residents' perception of indicators

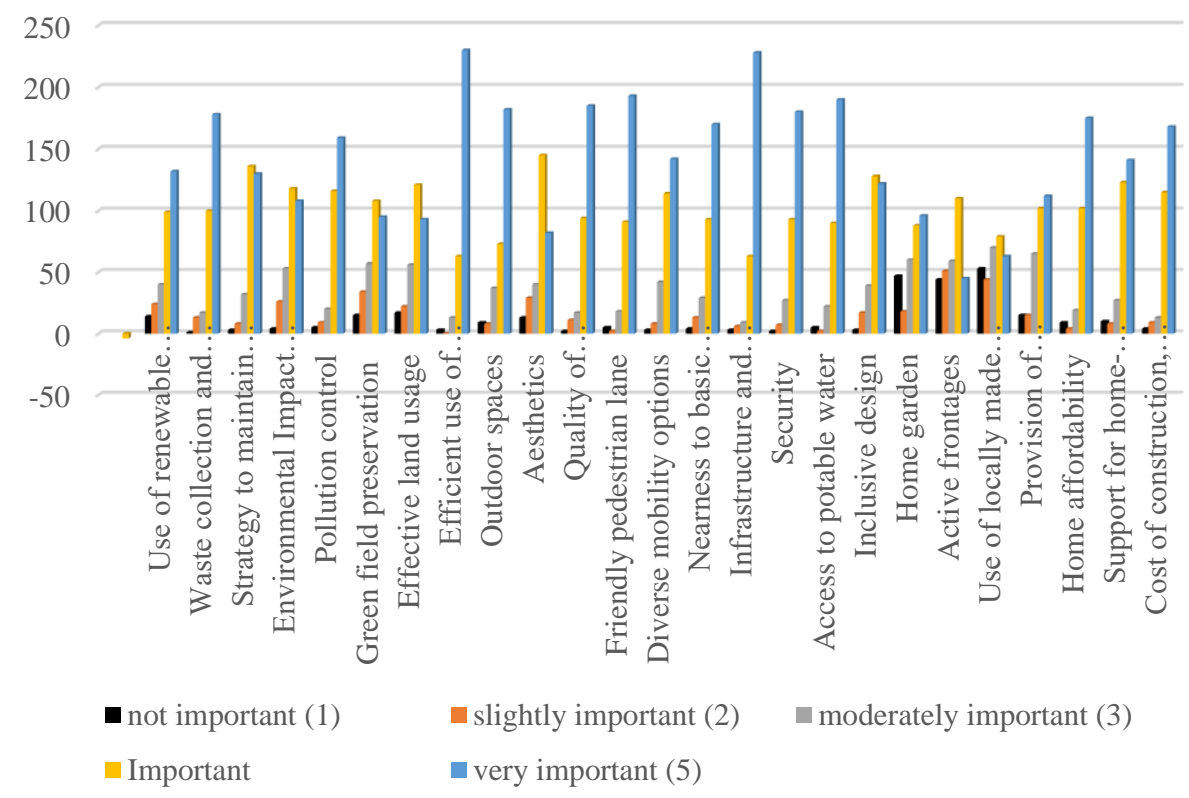

Figure 3: The frequency distribution of perceptions of residents on the importance of the indicators on a 5-point rating scale $(n=309)$.

Unlike the institutional stakeholders, none of the indicators was considered important by all the residents surveyed. About $80 \%$ of the residents perceived $15(60 \%)$ of the indicators as at least important. About $31 \%$ of the residents perceived the indicator 'Home garden' as not important in planning for a sustainable neighbourhood. The co-efficient of variation (CV) and the content validity ratio (CVR) of the indicators (Table 6) helped determine which of the indicators reached consensus on their importance according to stakeholders, and could subsequently be selected.

Table 6: The CV and CVR values of the indicators. Bold and italic font for emphasis.

\begin{tabular}{|l|l|l|l|l|}
\hline \multirow{2}{*}{ Indicators } & CV & CVR \\
\cline { 2 - 5 } & Institutions & Residents & Institutions & Residents \\
\hline Use of renewable energy & 0.34 & 0.33 & 0.71 & 0.50 \\
\hline $\begin{array}{l}\text { Waste collection \& } \\
\text { management }\end{array}$ & 0.36 & 0.34 & 1.00 & 0.80 \\
\hline Facility management & 0.35 & 0.34 & 0.90 & 0.72 \\
\hline $\begin{array}{l}\text { Environmental Impact } \\
\text { Assessment }\end{array}$ & 0.34 & 0.33 & 0.52 & 0.46 \\
\hline Pollution control & 0.34 & 0.34 & 0.81 & 0.78 \\
\hline Green field preservation & 0.33 & 0.34 & 0.52 & 0.31 \\
\hline
\end{tabular}




\begin{tabular}{|l|l|l|l|l|}
\hline Effective land usage & 0.33 & 0.34 & 0.52 & 0.39 \\
\hline Efficient use of resources & 0.34 & 0.35 & 0.52 & 0.90 \\
\hline Outdoor spaces & 0.35 & 0.34 & 0.71 & 0.65 \\
\hline Aesthetics & 0.35 & 0.34 & 0.24 & 0.47 \\
\hline Quality of construction material & 0.37 & 0.34 & 1.00 & 0.81 \\
\hline Good pedestrian lane & 0.36 & 0.35 & 1.00 & 0.84 \\
\hline Diverse mobility option & 0.33 & 0.34 & 0.71 & 0.66 \\
\hline $\begin{array}{l}\text { Nearness to amenities \& } \\
\text { infrastructures }\end{array}$ & 0.34 & 0.34 & 0.81 & 0.70 \\
\hline $\begin{array}{l}\text { Availability of infrastructure } \\
\text { \&amenities }\end{array}$ & 0.37 & 0.35 & 1.00 & 0.88 \\
\hline Security & 0.35 & 0.34 & 0.81 & 0.77 \\
\hline $\begin{array}{l}\text { Access to reliable and potable } \\
\text { water }\end{array}$ & 0.36 & 0.34 & 0.81 & 0.81 \\
\hline Inclusive design & 0.33 & 0.33 & 0.43 & 0.62 \\
\hline Use of locally made material & 0.33 & 0.44 & 0.43 & $\mathbf{- 0 . 0 8}$ \\
\hline $\begin{array}{l}\text { Provision of neighbourhood } \\
\text { square }\end{array}$ & 0.33 & 0.34 & 0.71 & 0.39 \\
\hline Home affordability & 0.34 & 0.34 & 0.52 & 0.79 \\
\hline $\begin{array}{l}\text { Support for home-based } \\
\text { business }\end{array}$ & 0.36 & 0.33 & 0.34 & 0.71 \\
\hline $\begin{array}{l}\text { Cost of construction, operation, } \\
\text { \& maintenance }\end{array}$ & 0.34 & 0.34 & 0.81 & 0.83 \\
\hline $\begin{array}{l}\text { Home garden for local food } \\
\text { production }\end{array}$ & $\mathbf{0 . 5 3}$ & 0.37 & $\mathbf{- 0 . 2 4}$ & $\mathbf{0 . 1 9}$ \\
\hline $\begin{array}{l}\text { Active frontages to encourage } \\
\text { shops }\end{array}$ & $\mathbf{0 . 7 8}$ & 0.43 & $\mathbf{- 0 . 7 1}$ & $\mathbf{0 . 0 0}$ \\
\hline
\end{tabular}

The CV values based on the institutional stakeholders' perceptions implied a high degree of consensus in their perceptions. However, 'active frontages' and 'home garden to support food' with a CV of 0.78 and 0.53 respectively, indicated that stakeholders' perceptions on their importance varied substantially. Therefore, the two indicators will not be selected because they have CVs greater than 0.5. On how essential an indicator is, there was considerable disagreement on 'home garden to support food', and 'active frontage for shops' with a CVR of -0.24 and -0.71 respectively. In contrast, 'waste collection and management'; 'good pedestrian lane'; 'availability of infrastructure and amenities' had a CVR of 1.00 indicating perfect agreement among stakeholders about how essential they are in planning for a sustainable neighbourhood. There was a similar result based on residents' perception. While no indicator had a CV below 0.5, three indicators had a CVR below 0.29: resulting in 23 indicators being selected as suitable for assessing a new neighbourhood development in metropolitan Lagos. Two were dropped as there was no consensus based on stakeholder perception on their importance in planning for a sustainable neighbourhood in metropolitan Lagos. 


\subsection{Ranking the Indicators}

A two-step process was used, combining two factors to arrive at a product that could be used to rank the indicators, as explained below.

\subsubsection{Sustainability dimensions}

Six out of the twenty-one institutional respondents (28.57\%) indicated equal preference for each of the sustainability dimensions i.e. economic, social, and environmental, while others had various combinations of preferences across the dimensions (Figure 4). This is the global priority value for each of the sustainability dimensions.

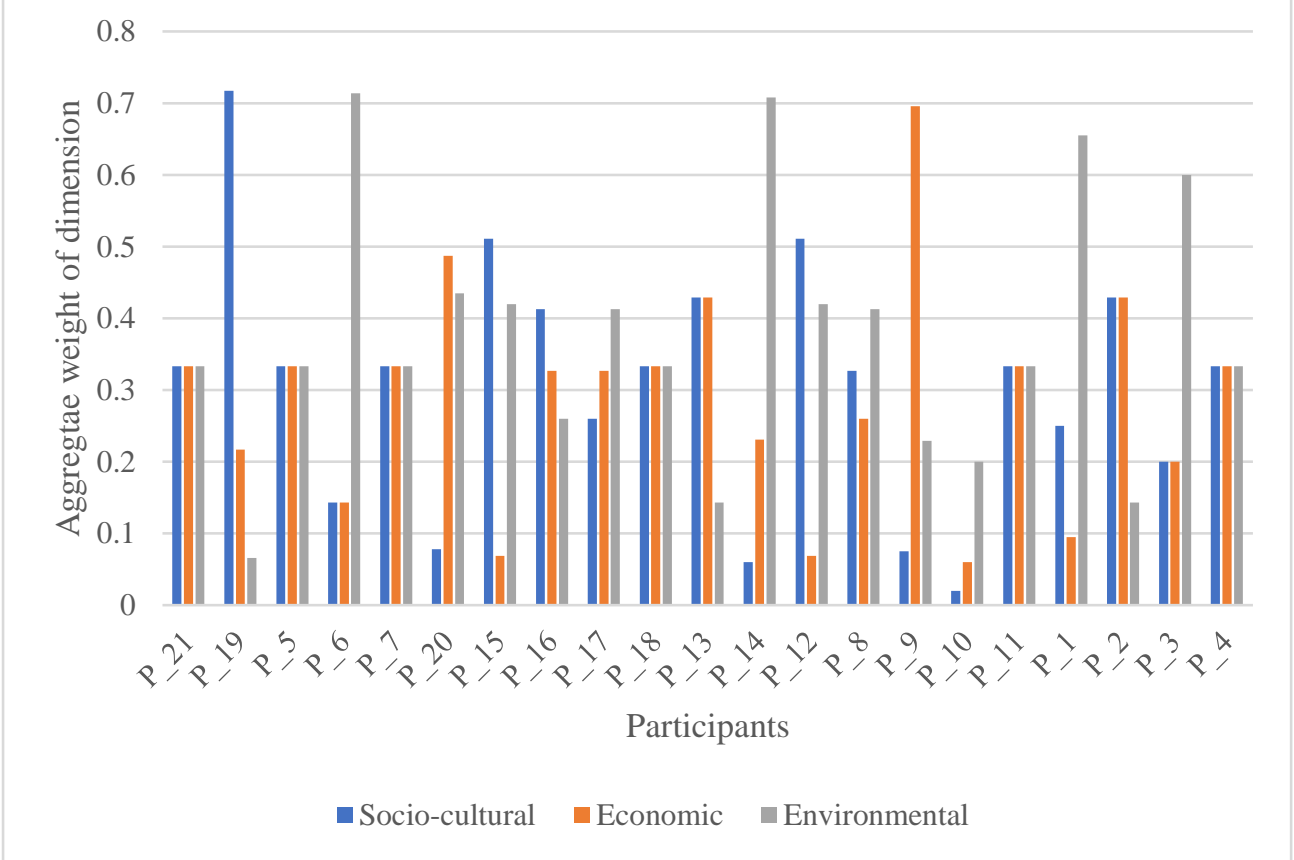

Figure 4: Aggregate of participant's preferences for sustainability dimensions.

However, the aggregate result from the stakeholders' preferences showed that the environmental dimension was ranked first with a weight of 0.379 , followed by economic ( 0.311$)$ and socio-cultural $(0.310)$.

\subsubsection{Individual indicators}

Table 10 shows stakeholders having varying perceptions of the importance of indicators within each sustainability dimension. The aggregate values for each indicator, known as the local priority value, shows the weight of the indicator when compared to other indicators under their respective dimensions. However, to establish the overall weight of an indicator (when compared with others within and outside its dimension), a global priority value (Shahin and Mahbod, 2007), showing the weight of an indicator when 
compared with all the other indicators, was calculated. This was done by multiplying the local priority value and the global priority value of the sustainability dimension to which it belongs (Table 7). For example, renewable energy with a local priority value of 0.89 has a global priority value of 0.037 (0.098 x 0.379).

Table 7: Ranking of the 23 indicators based on Global Priority values.

\begin{tabular}{|c|c|c|c|c|}
\hline \multirow{2}{*}{$\begin{array}{l}\text { Sustainability } \\
\text { dimensions } \\
\text { (global } \\
\text { priority) }\end{array}$} & \multirow[t]{2}{*}{ Indicators } & \multicolumn{2}{|l|}{ Weight } & \multirow[t]{2}{*}{ Rank } \\
\hline & & $\begin{array}{l}\text { Local } \\
\text { priority }\end{array}$ & Global priority & \\
\hline \multirow[t]{8}{*}{$\begin{array}{l}\text { Environmental } \\
(0.379)\end{array}$} & $\begin{array}{l}\text { Environmental Impact } \\
\text { Assessment }\end{array}$ & 0.169 & 0.064 & 4 \\
\hline & Efficient use of resources & 0.158 & 0.060 & 5 \\
\hline & Pollution control & 0.135 & 0.051 & 6 \\
\hline & $\begin{array}{l}\text { Waste collection and } \\
\text { management }\end{array}$ & 0.128 & 0.049 & 7 \\
\hline & $\begin{array}{l}\text { Strategy to maintain } \\
\text { infrastructure }\end{array}$ & 0.116 & 0.044 & 8 \\
\hline & Effective land usage & 0.107 & 0.040 & 9 \\
\hline & Use of renewable energy & 0.098 & 0.037 & 10 \\
\hline & Greenfield preservation & 0.090 & 0.034 & 11 \\
\hline \multirow{12}{*}{$\begin{array}{l}\text { Social-cultural } \\
(0.310)\end{array}$} & Access to potable water & 0.116 & 0.036 & 12 \\
\hline & $\begin{array}{l}\text { Availability of infrastructure / } \\
\text { amenities }\end{array}$ & 0.113 & 0.035 & 13 \\
\hline & Quality of construction material & 0.110 & 0.034 & 14 \\
\hline & Security & 0.100 & 0.031 & 15 \\
\hline & Nearness to basic amenities & 0.094 & 0.029 & 16 \\
\hline & Use of locally made material & 0.081 & 0.025 & 17 \\
\hline & Outdoor spaces & 0.071 & 0.022 & 18 \\
\hline & Diverse mobility option & 0.071 & 0.022 & 18 \\
\hline & Inclusive design & 0.065 & 0.020 & 20 \\
\hline & $\begin{array}{l}\text { Use of public arts / landscape } \\
\text { elements }\end{array}$ & 0.061 & 0.019 & 21 \\
\hline & Good pedestrian lane & 0.061 & 0.019 & 21 \\
\hline & Neighbourhood squares & 0.058 & 0.018 & 23 \\
\hline \multirow{3}{*}{$\begin{array}{l}\text { Economic } \\
(\mathbf{0 . 3 1 1 )}\end{array}$} & Cost of construction / operation & 0.398 & 0.124 & 1 \\
\hline & Home affordability & 0.324 & 0.100 & 2 \\
\hline & $\begin{array}{l}\text { Support for home-based } \\
\text { business }\end{array}$ & 0.278 & 0.087 & 3 \\
\hline
\end{tabular}

The reliability of the values was obtained by calculating the consistency ratios (CRs) for the environmental, social-cultural, and economic indicators which were $0.004,0.003$, and 0.002 suggesting that the data was sufficiently reliable. This is because, Saaty and Vargas (2013) suggests that if the CR exceeds 0.1 , then the set of judgments may be too inconsistent to be reliable. 
Based on the global priorities, there were some similarities in stakeholders' preferences across the various neighbourhoods. The preference for 'waste collection and management' over 'use of renewable energy' and 'strategy to maintain infrastructure'; and 'pollution control' over 'green field preservation' was the same with stakeholders (i) across the three neighbourhoods; (ii) among the institutional stakeholders; and the combined results of all residents. The residents' preference for 'quality of construction material' over 'provision of outdoor spaces'; and 'home affordability' over support for 'home-based businesses' was like that of institutional stakeholders.

\subsection{Validating the indicators}

A total of 9 participants from various backgrounds (Table 8) participated in testing the validity of the selected indicators. $77.7 \%$ of the respondents had more than 11 years of experience making their judgement as experts reliable.

Table 8: Respondents' level of agreement on comprehensiveness, ranking, and usability of the indicators on a 5 scale (1- strongly disagree; 2 - disagree; 3 - neutral; 4- agree; 5 - strongly agree).

\begin{tabular}{|l|l|l|l|l|}
\hline Participants & Role & $\begin{array}{l}\text { Experience } \\
\text { (Years) }\end{array}$ & $\begin{array}{l}\text { Neighbourhoo } \\
\text { ds involved }\end{array}$ & $\begin{array}{l}\text { Levels } \\
\text { agreement }\end{array}$ \\
\cline { 3 - 5 } & $\begin{array}{l}\text { Comprehensiven } \\
\text { ess (Importance) } \\
\text { Usability }\end{array}$ \\
\hline $\begin{array}{l}\text { Ministry of Works } \\
\text { (MoW) }\end{array}$ & $\begin{array}{l}\text { Developer } \\
\text { (Govt) }\end{array}$ & Above 20 & $0-5$ & 5 (4) 4 \\
\hline $\begin{array}{l}\text { Ministry of Housing } \\
\text { (MoH) }\end{array}$ & $\begin{array}{l}\text { Developer } \\
\text { (Govt) }\end{array}$ & Above 20 & $11-20$ & 5 (5) 5 \\
\hline $\begin{array}{l}\text { Lagos State Property and } \\
\text { Development Corporation } \\
\text { (LSDPC) }\end{array}$ & $\begin{array}{l}\text { Developer } \\
\text { (Govt) }\end{array}$ & $6-10$ & $0-5$ & 5 (5) 5 \\
\hline $\begin{array}{l}\text { Private Developer } \\
\text { (PDEV_1) }\end{array}$ & Developer & $11-20$ & $0-5$ & 4 (4) 4 \\
\hline $\begin{array}{l}\text { Private Developer } \\
\text { (PDEV_2) }\end{array}$ & Developer & $11-20$ & $11-20$ & 4 (4) 4 \\
\hline $\begin{array}{l}\text { New Town Development } \\
\text { Authority (NTDA) }\end{array}$ & Regulator & $0-5$ & $0-5$ & 5 (4) 5 \\
\hline $\begin{array}{l}\text { Ministry of Physical } \\
\text { Planning and Urban } \\
\text { Development (MPPUD) }\end{array}$ & Regulator & $11-20$ & $11-20$ & 5 (5) (4) \\
\hline $\begin{array}{l}\text { Lagos Building } \\
\text { Investment Company } \\
\text { (LBIC) }\end{array}$ & Regulator & $11-20$ & $11-20$ & 4 (4) 4 \\
\hline $\begin{array}{l}\text { Lagos Building Control } \\
\text { Agency (LABCA) }\end{array}$ & Regulator & $11-20$ & Above 20 & 5 (5) (4) \\
\hline Average & & & $\mathbf{4 . 6 7}$ (4.44) 4.33 \\
\hline
\end{tabular}


All the institutions, on average, strongly agreed on the comprehensiveness, and agreed on both the ranking and usability of the selected indicators. Their numerical scores (Table 8) on the criteria of comprehensiveness, importance and usability of the indicators, were equivalent to at least agree. This acted as a demonstration of validity that the selected indicators would likely be found useful in practice. Explaining their judgments, the MoH noted that "the development of sustainable cities and communities is one of the sustainable development goals (SDGs) to which Nigeria is a signatory." The MoW stated that "using the indicators in decisionmaking would ensure the delivery of quality housing to the end-users".

NTDA noted that "the indicators are strongly essential in decisionmaking for a new neighbourhood because they help to better design a functional neighbourhood and livelihood enhancing factors". PDEV_1 stated that they were "receptive to whatever will enhance the goal of affordable housing delivery both in quantity and quality which the indicator epitomises". LBIC posited that "if the aforesaid indicators are successfully put to use, a sustainable neighbourhood would be built, which would enhance the lives and properties of people"

\section{Discussion}

This section discusses the validity, reliability, and context specificity of the indicator set: allowing the researchers to tease out implications of the findings within a broader context. Validity is the property of a research instrument that measures its relevance, precision and accuracy (Dangana, 2015). This was enhanced by applying statistical techniques which tested hypotheses and showed levels of statistical confidence. The tests were used in a confirmatory approach so that $\mathrm{CV}, \mathrm{CVR}$ and AHP results were considered together, akin to triangulation, to reach a more robust decision about which indicators carried what levels of importance among stakeholders. External validity, referring to the generalizability of the findings was enhanced by the research design being grounded in the Lagos context, which is representative of several SSA urban areas. The deference to critical realism as a philosophical lens provided insight that was more grounded in the contextual reality of metropolitan Lagos.

Reliability assures that the same result would be obtained if the research is repeated in a similar context. This was enhanced through the transparency of the research design and process, from the research assumptions to the identification of the research participants, to data collection and analysis.

While several approaches can be applied to selecting indicators, this paper offers one that robustly demonstrates its evidence and reliability. It showcases justified, repeatable and auditable steps, with opportunities for 
flexibility in the choice of stakeholders, methods and techniques. While certain techniques like Analytical Hierarchy Process (AHP) were used, others could have been applied. As long as they are justifiably and transparently used to deliver robust results and achieve the intended purposes. The techniques used provided clear evidence as to the reliability about the collective ranking and importance of an indicator; as well as level of trust in the choice; a problem that has beset the selection of most indicators in existing NSAFs. As the indicators are supposed to serve local and contextual needs, internal rather than external validity and reliability, should be prioritised. Overall, a key advantage in the methodology and workflow presented herein is that there are no onerous technological, methodological, data or resource requirements, making it feasible across many SSA cities.

A workflow consists of an orchestrated and repeatable pattern of activity, enabled by the systematic organization of resources into processes that transform materials, provide services, or process information. It can be depicted as an abstract or higher-level perspective, as a sequence of operations or mechanisms to achieve a purpose or deliver an outcome. Simply put, workflows are the way people get work done, illustrated as series of steps or instructions to be completed sequentially (Table 1), showing work flowing from one stage to the next, whether through a colleague, tool, or another process. Originated by Henry Gantt who invented the ubiquitous Gantt charts, workflows can be considered as efficient ways of organizing work. They helps us see (i) the exact jobs to be done, (ii) by whom and (iii) time needed, so tasks can be managed and executed optimally.

\section{Conclusion}

This paper has shown a robust methodology and workflow that can objectively be used to select an indicator set for NSAFs in SSA, based on data from metropolitan Lagos, Nigeria. By detailing the rationale and steps of application, it enhances transparency, repeatability, and adoptability to other SSA contexts. The paper has value in showing how challenging issues around the ranking and prioritising of a wide range of indicators, amongst a broad spectrum of stakeholders, can be more objectively undertaken. Planning practitioners and policymakers should find this an easy canvass / template upon which to reflect and even work from: instead of investing time and resources to cover ground already done in this paper.

However, some methodological limitations in this study can be identified. Reliance on stakeholders' opinions could introduce bias and subjective influences which the study could not control for. Also, some of the respondents may have understood the same questions and terms differently. The fact that there was statistical significance in a finding does not necessarily mean this translates into significance based on people's real lives. Finally, 
while the study is contemporary and offers a snapshot in time, it is possible to assume that preferences are transient and not immutable.

As the research design was driven by critical realism, the observed data largely reflected the influence of the existing reality of metropolitan Lagos stakeholders' perceptions and preferences of a sustainable neighbourhood. However, it cannot be denied that there is some porosity as the professional stakeholders, to a degree, appeared to be imbued with notions of sustainability aligned to a more international discourse. Brundtland's more globalised definition of sustainability could be identified in mostly the institutional perceptions, but not in the local residents'. This shows the complexity in locating what can be demarcated as exclusively global or local in nature, and where and how they should be balanced.

It is only by combining a top-down and a bottom-up approach in this study, was it possible to capture such nuanced and/or complex views. This is further credit to critical realism, which helped to account for the effects existing reality in metropolitan Lagos. For example, affordability of a neighbourhood or waste management, and pollution control, strongly emerged amongst the resident's perceptions. For the regulators and policy-makers, the notion that sustainable neighbourhood should be concerned with intergenerational and intra-generational equity, and costs of construction and maintenance, were highly rated. In terms of future research, ways of better integrating aspects of costs and data availability, in the indicators selection, is required, as they influence whether indicators are used or not.

\section{References:}

1. Akadiri, O., 2011. Development of a multi-criteria approach for the selection of sustainable materials for building projects, $\mathrm{PhD}$ thesis, Wolverhampton: University of Wolverhampton.

2. Ameen, R. F. \& Mourshed, M., 2019. Urban sustainability assessment framework development: The ranking and weighting of sustainability indicators using analytic hierarchy process. Sustainable Cities and Society, Volume 44, pp. 356-366.

3. Awumbila, M., 2017. Drivers of migration and urbanisation in Africa: Key trends and issues. Background paper prepared for UN expert group meeting on sustainable cities, human mobility and international migration 7-8 September, New York: UN.

4. Ayre, C. \& Scally, A. J., 2014. Critical Values for Lawshe's Content Validity Ratio: Revisiting the Original Methods of Calculation. Measurement and Evaluation in Counseling and Development, 47(1), pp. 79-86. 
5. Bahadure, S. \& Kotharkar, R., 2018. Framework for measuring sustainability of neighbourhoods in Nagpur, India. Building and Environment, Volume 127, pp. 86-97.

6. Bell, S. \& Morse, B., 2004. Experiences with sustainability indicators and stakeholder participation: A case study relating to a "blue plan" project in Malta. Sustainable Development, Volume 12, pp. 1-14.

7. Bell, S. \& Morse, S., 2008. Sustainability Indicators- Measuring the Immeasurable?. 2nd ed. London: Earthscan.

8. Berardi, U., 2013. Sustainability assessment of Urban communities through rating systems. Environment development and sustainability, pp. 1573-1591.

9. Bond, A., Morrison-Saunders, A. \& Howitt, R., 2012. Framework for comparing and evaluating sustainability assessment practice. In: A. Bond, A. Morrison-Saunders \& R. Howitt, eds. Sustainability assessment: Pluralism, practice, and progress. London: Routledge, pp. 117-131.

10. Bullock, C., Brereton, F. \& Bailey, S., 2017. The economic contribution of public bike-share to the sustainability and efficient functioning of cities. Sustainable Cities and Society, Volume 28, pp. 76-87.

11. Cheng, E. W. L., Li, H. \& Ho, 2002. Analytic hierarchy process (AHP): A defective tool when used improperly. Measuring Business Excellence, 6(4), pp. 33-37.

12. Conte, E. \& Monno, V., 2012. Beyond the buildingcentric approach: A vision for an integrated evaluation of sustainable buildings. Environmental Impact Assessment Review, pp. 31-40.

13. Cowley, R., Joss, S. \& Rydin, Y., 2013. Taking Stock: Current Research, Policy and Practice in 'Eco-City' Indicators, Standards and Frameworks, London: University of Westminster.

14. Dahl, A., 2012. Achievements and gaps in indicators for sustainability. Ecological Indicators, Volume 17, pp. 14-19.

15. Dangana, S., 2015. A decision support framework for selecting innovative sustainable technologies for delivering low carbon retail buildings, Plymouth: Unpublished Thesis; Doctor of Philosophy.

16. Dawodu, A., Akinwolemiwa, B. \& Chesmehzangi, A., 2017. A conceptual re-visualization of the adoption and utilization of the Pillars of sustainability in the development of neighbourhood sustainability assessment tools. Sustainable Cities and Society, Volume 28, pp. 398410.

17. Du Plessis, C., 2005. Action for sustainability: preparing an African plan for sustainable building and construction. Building Research and Information, 33(5), pp. 405-415. 
18. Ferwati, M., Al Saeed, M., Shafaghat, A. \& Keyvanfar, A., 2019. Qatar Sustainability Assessment System (QSAS)- Neighbourhood Development (ND) Assessment Model: Coupling green urban planning and green building design. Journal of Building Engineering, Volume 22, pp. 171-180.

19. Fletcher, A. J., 2017. Applying critical realism in qualitative research: methodology meets method. International Journal of Social Research Methodology, pp. 181-194.

20. GBCA, 2012. Green Star Communities: Guide for Local Government, Melbourne: Green Building Council Australia.

21. Gehl, J. \& Svarre, B., 2013. How to study public life. Washington: Island Press.

22. Hak, T., Kovanda, J. \& Weinzettel, J., 2012. A method to assess the relevance of sustainability indicators: Application to the indicator set of the Czech Republic's sustainable development strategy. Ecological Indicators, Volume 17, pp. 46-57.

23. Joss, S., Cowley, R., Mueller, B., Park, B.S., Rees, W., Roseland, M., Rydin, Y., \& de Jong, M., 2015. Tomorrow's City Today: Prospects for Standardising Sustainable Urban Development, London: University of Westminster.

24. Komeily, S. \& Srinivasan, R., 2015. A need for a balanced approach to Neighbourhood Sustainability Assessment. Journal of sustainable cities and society, Volume 18, pp. 32-43.

25. La Porta, R. \& Shleifer, A., 2014. Informality and Development. Journal of Economic Perspectives, 28(3), pp. 109-126.

26. LASG, 2013. Lagos State Development Plan (2012-2025), Lagos: Ministry of Economic Planning and Budget.

27. Lawshe, C. H., 1975. A quantitative approach to content validity. Personel psychology, Volume 28, pp. 563-575.

28. Moroke, T., Schoeman, C. \& Schoeman, I., 2019. Developing a neighbourhood sustainability assessment model: an approach to sustainable urban development. Sustainable Cities and Society, Volume 48.

29. Olvera, I., Guezere, A., Plat, D. \& Pochet, P., 2016. Earning a living but at what price? Being a motorcycle taxi driver in a Sub-Saharan African city. Journal of Transport Geography, Volume 55, pp. 165174.

30. Saaty, T. L. \& Peniwati, K., 2008. Group Decision Making: Drawing out and Reconciling Differences. Pittsburgh: RWS Publications.

31. Saaty, T. L. \& Vargas, L. G., 2013. The Analytic Network Process. In: Decision Making with the Analytic Network Process. International 
Series in Operation Research and Management Science. Boston, MA: Springer.

32. Saghir, J. \& Santoro, J., 2018. Urbanisation in sub-Saharan Africa: Meeting Challenges by Bridging Stakeholders. Washington DC: Centre for Strategic and International Studies.

33. Salama, A. M., 2019. Methodological research in architecture and allied disciplines. International Journal of Architectural Research, 13(1), pp. 8-24.

34. Schmidt, K. et al., 2015. Applying the Analytical Hierarchy Process in healthcare research: A systematic literature review and evaluation of reporting. Medical Informatics and Decision Making, 15(112).

35. Science for Environment Policy, 2015. In-Depth Report: Indicators for Sustainable Cities: Bristol, Bristol: European Commission DG Environment by the Science Communication Unit.

36. Shahin, A. \& Mahbod, M., 2007. Prioitization of key performance indicators: An integration of analytical hierarchy process and goal setting. International Journal of Productivity and Performance Management, 56(3).

37. Stanislav, A. \& Chin, J. K., 2019. Evaluating livability and perceived values of sustainable neighbourhod design: New Urbanism and original urban suburbs. Sustainable Cities and Society, Volume 47.

38. Tetteh, N. \& Amponsah, O., 2020. Sustainable adoption of smart homes from the Sub-Saharan African Perspectives. Sustainable Cities and Society, Volume 63, p. 102434.

39. UNDESA, 2019. World Population Prospects 2019: Highlights (ST/ESA/SER.A/423), s.l.: United Nations.

40. UNEP, 2020. The new neighbourhood: creating new community around sustainability and social wellbeing, Kenya: UN environment programme.

41. UN-Habitat, 2015. State of Africa Cities: Re-imagining sustainable urban transitions.

[Online]

[Accessed 0911 2015].

42. UN-Habitat, 2016. Urbanisation and development: Emerging futuresWorld Cities report 2016, Nairobi: United Nations Human Settlements Programme (UN-HABITAT).

43. USGBC, 2018. LEED ND V4 for Neighbourhood Development, Washington: US Green Building Council.

44. Wangel, J., Wallhagen, M., Malmqvist, T. \& Finnveden, G., 2016. Certification systems for sustainable neighbourhoods: What do they really certify?. Environmental Impact Assessment Review, Volume 56, pp. 200-2013. 
45. Wilson, F., Pan, W. \& Schumsky, D., 2012. Recalculation of the critical values for Lawshe's content validity ratio. Measurement and Evauation in Counselling and Development, Volume 45, pp. 197-210.

46. Yigitcanlar, T. \& Lee, S., 2014. Korean ubiquitous eco-city: A smartsustainable urban form or a branding hoax?. Technological Forecasting and Social Change, Volume 89, pp. 100-114. 